\title{
DESCENT OF GLACIERS: SOME EARLY SPECULATIONS ON GLACIER FLOW AND ICE PHYSICS
}

\author{
By J.C.F. WALKER \\ (School of Forestry, University of Canterbury, Christchurch 1, New Zealand) \\ and E.D. WADDINGTON
}

(Graduate Program in Geophysics AK-50, University of Washington,

Seattle, Washington 98195 , U.S.A.)

\begin{abstract}
Scheuchzer's dilatation theory and Altmann's rigid sliding theory were the first glacier-flow theories to receive serious scientific attention. When Agassiz began a research program at Unteraargletscher in 1839, he held several incorrect notions about glacier flow. Forbes understood the difficulties with the existing theories, and in the early $1840 \mathrm{~s}$ he and Agassiz acquired motion, temperature, and structural data that were incompatible with the dilation and sliding theories but were suggestive of flow analogous to that of a viscous fluid. How an apparently brittle rigid solid like ice could flow became the central paradox requiring explanation. Some of the most able physicists of the mid-nineteenth century went through contortions in their largely misguided efforts to explain the viscous behaviour in terms of the known physics of rigid solids. Personality and speculation played a far larger part in their debates than we see in scientific discussions today.
\end{abstract}

IN THE Middle Ages when few, apart from chamois hunters, ventured high in the Alps, popular belief held rock crystal to be a harder form of ice, and not until the eighteenth century did men of science give serious attention to the question of glacier flow. Clarke (1987) has given an overview of early glacier-flow theories as part of a recent history of scientific studies on glaciers. We wish to discuss in more detail some of the issues involved in the early to mid-nineteenth century.

One of the earliest scientific observers was Scheuchzer (1723), a doctor and naturalist of Zürich, following a visit to the glaciers of the Savoy in 1705 . He wrote to astonish as well as to edify, extolling and embellishing on the marvels of the Alps - delighting in particular on the subject of dragons. Amidst such excitements there are comments on glaciers and other phenomena. Scheuchzer supposed that melt water flowed into cracks and fissures within the glacier and froze, and expanding with irresistible force urged the glacier down-hill. In this manner, the chapel of St Petronilla in the Grindelwald valley, with houses, trees, and pastures, were all destroyed by the advancing glacier. He wrote (in poor mediaeval Latin):

"... this gradual increase in size and its consequences is attributed to some miracle by those who, ignorant of natural science, engage in fantasies, but it should be ascribed entirely to natural causes. For it is a fact that the water which flows down from the mountain slopes and icy heights and collects in crevices and other confined spaces in the ice, freezes and, since it requires a greater amount of room in this state (as shown by experiments used to demonstrate the properties of cold and ice), it exerts pressure in all directions. By doing this it raises the upper surface of the ice and by the same act propels the pastures downhill, together with the ice, sand, stones, and even boulders of some considerable size. The excessive scouring can also be easily explained and understood from this thrusting movement" (Scheuchzer, 1723, vol. 4 , p. 287-88).

This theory of dilation was to be revived independently by Toussaint von Chapentier (1819).

Altmann (1751) and Gruner (1760) were advocates of an alternative school of thought whereby a glacier, rather than advancing by dilation, slid on its bed under its own weight assisted by melting at its sides. The glacier, they believed would move forward in fits and starts, being stayed in its course by obstacles until these were overcome by melting of the ice beneath or by the accumulative weight of the ice and snow above and behind. Kuhn, in 1783 , reported just such an event:

"All at once, from towards the east at the foot of the Schreckhorn, a mighty rumble, like a clap of thunder passed beneath my feet. At the same moment the ice field was powerfully shaken, and two very strong shocks, resembling those of a horizontal earthquake, followed each other, crash upon crash, in the direction of the roar beneath the surface. Various rocks, resting on sloping ground at my side started to move, and rolled into neighbouring hollows. Two very wide crevasses nearby suddenly closed up and the water in them was forced into the air with a great noise. I myself was thrown down by the violence of the shocks.

According to this experience therefore, the movement of the glaciers bring about their progress, is caused by one or more shocks, which spread from a focal point through the whole mass, and move it one or two steps forward, sometimes more, sometimes less" (see de Beer, 1953).

Such an occurrence must be treated as a highly singular event!

Gruner imagined the glacier floated on water imprisoned between rock and ice so the ice need not conform to the profile of its bed. De Saussure (1803), contrary to other opinion, suggested that sliding occurred smoothly and continuously (C'est ce glissement lent mais continue des glaces, p. 454), aided by the lubricating influence of geothermal heat. Also, de Saussure admitted an element of flow within the ice, as in the broadening of the glacier of Mont Dolent (p. 860).

In 1837, little was known about glaciers, save that they moved, could transport material, and erode bedrock; indeed, only de Saussure (1803) and Hugi (1830) had spent much time exploring and investigating their forms. Repeated observations by Hugi (1830) and later by Agassiz (1840, p. 150) of the position of Hugi's hut on the medial moraine of Unteraargletscher (Fig. 1) provided one of the earliest quantitative estimates of glacier velocity, although Clarke 


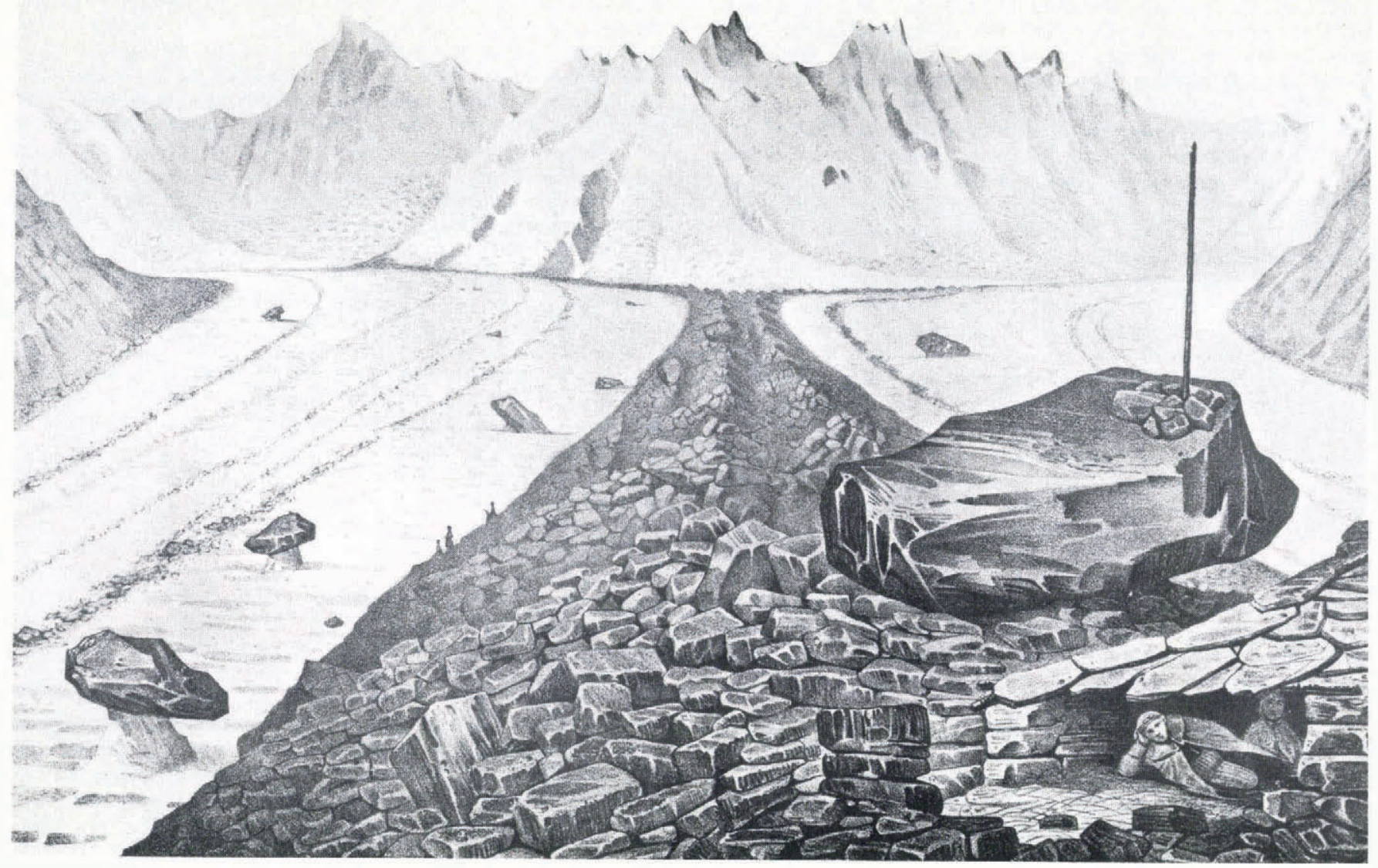

Fig. 1. Hugi's hut on the medial moraine of Unteraargletscher below the confluence of the Lauteraargletscher (left) and Finsteraargletscher (right). The hut moved from the foot of the rock Im Abschwang (centre) to this location in 13 years. This moraine was the site of Agassiz' Hôtel des Neuchatelois, while he conducted research here in 1840. (With permission of the Rector. Université de Neuchâtel.)

(1987) has pointed out inconsistencies in their estimates. Theories regarding the origin, movement, and physical characteristics were generally pure speculation. Agassiz's Etudes sur les glaciers (1840) revealed a number of misconceptions that could only be disproved by careful field work:

(1) That ice at the edges moves faster than at the centre (p. 86,167$)$.

(2) That glaciers do not move in winter (p. 212).

(3) That significant quantities of surface melt water freeze while percolating through the ice to bedrock ( $p$. 173-75).

(4) That glaciers are reservoirs of cold and frozen to their beds (at least at high altitudes) (p. 172-73, 203, 213).

(5) That melting and freezing played an important role in the transformation of snow into glacier ice (p. 33ff, 139ff).

To defend and define his position, scientific study of glaciers was necessary. With patronage from the King of Prussia, Agassiz made regular expeditions establishing a base on the Aar. His famous Hôtel des Neuchatelois, under part of an immense block on the same central moraine as Hugi's hut (Fig. 1) about $1 \mathrm{~km}$ below the confluence of Finsteraargletscher and Lauteraargletscher, was a mere $3.5 \mathrm{~m}$ by $1.8 \mathrm{~m}$ and at best $1.2 \mathrm{~m}$ high with a double covering of wax cloth over the ice. It can never have been comfortable; the rock was badly fissured and the roof leaked (Agassiz, 1842a). By 1846 the block had split in two.

James David Forbes, Professor of Natural Philosophy at Edinburgh, visited Agassiz on the Aar in August 1841 and, that winter, reviewed the state of glaciological knowledge
(Forbes, 1842a), noting the deficiencies in existing hypotheses for glacier flow. With the theory of sliding, gravity was the driving force aided by geothermal heat. Here, the principles were clear and the evidence demonstrative: the erosive pattern of a glacier moving on bedrock and the copious streams, laden with detritus and rock flour, issuing from the base of the glacier. Yet, its detractors could not see how a glacier could move down a shallow valley whose slope might be $3^{\circ}$ or less, or how a rigid glacier could move over an uneven bed and around corners. In addition, the theory predicted that a glacier should move during all seasons, yet this was not thought to occur: the glacier was presumed to be frozen to its walls in the winter. Indeed, theoretical calculations showed that geothermal heat would not be able to raise the temperature at bedrock to $0^{\circ} \mathrm{C}$ at elevations over $6165 \mathrm{ft}$ [2023 m] (Agassiz, 1840, p. 213), so any such glacier would be restrained from sliding by its frozen tail.

The dilation theory, on the other hand, assumed the ice to be minutely fissured and cracked into many angular fragments, some $10-40 \mathrm{~mm}$ in diameter according to Agassiz (1840, p. 31). Surface melt water was thought to percolate into these innumerable capillaries and freeze; the less compact the ice, the more water it could absorb and the more it would dilate. Thus, the glacier only moved when melt was plentiful, while in winter it would be inactive. Similarly, the margins of the glacier were assumed to move faster then the centre: the greater heat reflected from the valley walls caused much local melting and disintegration of the ice, thus enhancing dilation when entrapped water refroze at night. The crescent pattern, convex towards the up-stream direction, which characterized so many crevasse systems, was seen as proof of this differential movement. Finally, dilation of the glacier through to its base was compatible with bedrock erosion. However, there were two difficulties. First, resistance to dilation must be considerable both across and along the glacier, so consequently one might expect most of the expansion on freezing to be directed 
upwards, towards the surface, rather than to extend the length of the glacier. Secondly, it was not clear how the freezing process worked. It was not well appreciated that large amounts of energy must be abstracted from water to freeze it. The glaciers were simply considered to be great magazines of cold into which melt water percolated and froze, penetrating progressively deeper as the ice yielded up its cold to provide the latent heat of freezing. The dilation was thought to occur deeper within the glacier as it descended into the valley, or as summer progressed (the reservoir of cold could be either that accumulated in the high mountains or recharged every winter).

Initially, Agassiz's field studies were concerned with the geological aspects of glaciation, but in 1840 he began studying the glaciers themselves. That summer he drilled a hole to $7 \frac{1}{2} \mathrm{~m}$ depth in the lower Aar and found the temperature to be between $0^{\circ}$ and $-1 / 3^{\circ} \mathrm{C}$ (Agassiz, 1840, p. 203). Subsequent studies showed the body of the glacier was at the melting point; there was no natural reservoir of cold to freeze the infiltrating water. He then suggested that the cold of the summer night might freeze the water and its effect would be most marked near the surface; poor thermal conduction of ice would restrict its effect to the first few feet or so. Agassiz (1840, p. 165-66) asserted that superficial motion was fastest due to its own dilation, whilst surface ice was also being carried along by the relatively slower motion of the underlying ice. Unfortunately, this modification of the dilation theory reduced the efficiency of bedrock erosion which was one of the few partially understood facts of glacial action.

In September 1841, at the end of an active season on the Aar, Agassiz, prompted by Forbes, laid out a straight line of stakes across the glacier to determine its velocity. When re-measured in July 1842 , those stakes near the centre of the glacier had moved furthest down the valley - completely contrary to Agassiz's expectations. Reality was rather different from pre-conceptions (Agassiz, 1942a).

That same year Forbes went to Chamonix to survey the Mer de Glace. Placing a theodolite on the ice, he first surveyed its daily motion relative to the valley wall, and then its diurnal movement. The motion was slight, roughly $0.4 \mathrm{~m} / \mathrm{d}$. It varied little from day to day, or between day and night, with no sudden fits or periods of inactivity. Next, survey points were laid out across the glacier a short distance below Montanvert. Forbes observed, like Agassiz, that the centre moved faster than the sides. Finally, he measured the velocity of the ice along part of the length of the Mer de Glace, finding this to be fastest at its lower end, slowest around the middle of its length, and somewhat faster again near its top. Such variation he attributed in part to changes in the thickness of the glacier and the width of the valley in which it lay. He left his assistant Auguste Balmat to mark the progress of a great rock below Montanvert; its velocity in winter was still a large fraction of that in the summer.

In a single season, Forbes (1842b) had completed a few crucial observations, measured with impressive accuracy, of ten to $5 \mathrm{~mm}$, under conditions of some difficulty. The results were the antithesis of the dilation theory. The dilation theory of glacier flow could no longer be considered to be tenable.

Variable motion along the length of the glacier; the velocity should have been minimal near the névé and greatest at its lower extremity if the glacier dilated.

No vertical dilation during a cold spell in summer.

Movement in winter as well as summer when temperatures are below freezing.

On examination, Forbes considered the universality of capillary fissures questionable and the existence of large crevasses not readily accountable by the dilation theory.

Later, Canon Moseley (1855) proposed a somewhat similar idea but he relied instead on the high thermal expansion coefficient of ice. He thought a glacier might extend when warmed through thermal conduction and radiation, and contract again as it cooled, drawing its tail a small distance down-hill. Moseley drew an analogy with the thermal movement (crawling) of lead which had not been correctly fixed at the ridge on the roof of Bristol Cathedral when renewed in 1851 and had descended 18 in [46 cm] into the gutter 2 years later. His mechanism, seemingly, had advantages over the older dilation theory since light, and so by inference, thermal radiation penetrates glacier ice to a considerable depth (later Moseley was to speculate on the use of ice lenses for astronomical telescopes in countries where the temperature was below freezing for 2-3 months of the year!). Two months later, Forbes (1855) replied, arguing that in summer the glacier was charged with percolating water and the whole system would be at $0^{\circ} \mathrm{C}$; consequently, the glacier could not expand thermally, rather it would melt. Indeed, motion ought to be greater in winter when ice temperatures fluctuate below $0^{\circ} \mathrm{C}$. Moseley's proposition lay some 10 years ahead and its demise concluded most speculation that relied on forces in addition to gravity to move a glacier.

Forbes (1842b) deduced from the transects of 1842 that glaciers behaved like viscous bodies. Much earlier, Bordier (1773) had suggested that glacier ice might not be entirely rigid and immobile but rather behave either as a heap of coagulated matter, or as softened wax, flexible and ductile to a certain point. Sveinn Pàlsson (1945, p. 478) reached the same conclusions independently in Iceland in 1793, comparing glacier movement to the flow of pitch. However, his writings remained unpublished for 152 years (see Thorarinsson, 1960). While apparently unaware of Bordier's book, Rendu (1840), later Bishop of Annecy, supposed a glacier was viscous and able to mouid itself to the ground over which it moved. In 1838 he had noted the position of two rocks on the Mer de Glace; a year later one had moved $120 \mathrm{~m}$ and the other had disappeared (Rendu, 1840, p. 73). After questioning his guides about an enormous rock at the edge of the glacier, he estimated that it had moved $12 \mathrm{~m} /$ year for the last 5 years. This provided some support for his intuitive belief:

"There is between the Mer de Glace and a river a resemblance so complete that it is impossible to find in the glacier a circumstance which does not exist in the river. In currents of water the velocity is not uniform throughout their width nor throughout their depth; the friction of the bottom, that of the sides, the action of obstacles cause a variation in the velocity which is undiminshed only towards the middle of the surface. Now, the mere inspection of the glacier is sufficient to prove that the velocity of the centre is greater than that of the sides" (Rendu, 1840, p. 85).

With reference to the glacier of Mont Dolent, to which de Saussure (1803, p. 860 ) referred, Rendu said:

"There are a host of facts that would seem to induce the belief that the substance of glaciers enjoys a kind of ductility which allows it to mould itself upon the locality which it occupies - to thin out, to swell, to contract, and to spread as a soft paste would do Nevertheless, when we deal with a piece of ice, when we strike it, we find in it a rigidity which is in direct opposition to the appearances of which we have just spoken. Perhaps experiments made upon larger masses would give other results" (Rendu, 1840, p. 71).

Forbes accepted Rendu's notion of glacier flow. The viscous motion of a glacier, he maintained, was not a theory but a fact. He even devised experiments to simulate glacier flow where Plaster of Paris was mixed with glue and poured down irregularly modelled channels. To many of his critics, it was an equally certain fact that ice was a brittle solid and so it was nonsense to ascribe to it the terms viscous, semi-fluid, or plastic.

Thus, in order to establish the viscous flow theory as fact, Forbes was obliged as a physicist to resolve the central paradox identified by Rendu; he needed to explain the physics that allowed solid ice to flow like a fluid, i.e. to reduce the problem to known physical principles.

Forbes' own writings are ambiguous on this point. His 
groping attempts to explain ice viscosity reflect the lack of a general physical and mathematical paradigm of materials rheology. Without access to concepts of recrystallization, crystal surface energies, and dislocation motion, Forbes could only attempt to formulate his intuitive grasp of viscous flow in terms of the physics of rigid solids, clearly an inappropriate paradigm (it must have been frustrating for him).

Initially, he made a fine case by analogy with the plasticity of hard bodies such as tar or sealing wax which are brittle under a hammer but if left will mould themselves to the most delicate of surfaces on which they lie (Forbes, 1843a). In 1844, reference was made to hot lava and sealing wax but plasticity was not seen as an intrinsic characteristic of ice itself; solid crystalline ice does not "admit such a flexibility or yielding of parts as should permit any comparison to a fluid or semi fluid body". The movement of a glacier is rather a consequence of it being penetrated by water to all depths, with tremendous hydrostatic pressures moving "the vast, porous, crackling mass of seemingly rigid ice, in which it is, as it were, bound up". Forbes (1846) again remarked on the effect of time on the behaviour of apparently brittle solids:

"The efficiency of time being chiefly this, that a pressure insufficient to produce instant detrusion, will, sooner or later, cause the particles to slide insensibly past one another, and to form new attachments, so that the change of figure may be produced without positive rupture, which would reduce the solid to a heap of fragments. This change may either take place without any loss of homogeneity, or by numerous partial and minute rents not everywhere communicating, and therefore not necessarily destructive of cohesion, which may be termed a bruise."

This bruising of ice would allow the material to display some degree of apparent ductility and so move forward under fluid pressure exerted by the capillary water within the glacier.

In Travels through the Alps, Forbes (1843b) made a number of attempts to explain his concept of viscous flow of ice.

"In a perfect fluid there can never be a discontinuity of the mass such as may leave an unfilled separation or crack. The result of all the pressures and tensions must be resolvable into a sliding of one particle past another. As a body passes from the fluid, through the viscous or plastic state, into that of a solid, the sliding separation is combined with the formation of open fissures transverse to the lines of tension along which the sliding separation had taken place, and ultimately in the solid form, the division is usually entirely due to simple fracture." (Forbes, 1843b, p. 382)

Forbes clearly saw an intimate connection between the pattern of ice flow and the pattern of foliation (the "veined structure").

"The facts of motion and the facts of structure in a glacier [i.e. the bruising of the ice in the veins], the two mutually supporting and confirming one another, lend strong countenance to a theory which includes both." (Forbes, 1843b, p. 383)

Foliation, consisting of concave-upward, spoon-shaped alternating thin $(1-10 \mathrm{~cm})$ layers of bubble-free blue ice and bubbly white ice, resembled structures developed in laboratory flume experiments by flowing fluids widely recognised to be viscous. The veined structure was best developed near the glacier margins where the ice was strongly sheared. While it lay nearly parallel to the valley sides, it was inclined towards the centre in the down-stream direction. After careful observations of foliation on Mer de Glace, Unteraargletscher, and Rhonegletscher, Forbes (1843b, p. 374; reproduced here as Figure 2) showed its correct three-dimensional form. While foliation is related to flow, his explanation relied on repeated brittle fracture rather than plastic strain of pre-existing textural variations:
"The ice will, therefore be rent by innumerable fissures whose general direction will be parallel to its motion, and these fissures becoming filled with water and ultimately frozen, will produce the appearance of bands traversing the general mass of the ice having a different texture." (Forbes, 1843b, p. 170)

There are difficulties in appreciating the nuances; Forbes made no distinction between viscous, plastic or semi-fluid, while a solid body was deemed incapable of deformation. Clearly, it is inappropriate to attach modern meaning to these terms.

An ingenious attempt by Hopkins (1843a, b) to marry the brittleness of ice to the apparent viscous flow of a glacier alluded to the formation and closure of crevasses which left surfaces of discontinuity where cohesion was never more than partly restored. Although crevassing is rarely parallel to the length of the glacier, the faster flow in the centre would rotate transverse and lateral crevasses (after they had closed up again), thus the ice becomes criss-crossed by planes of low cohesion, breaking the glacier up into individual fragments or blocks which can move relative to one another. Sliding and crushing of ice along these vertical fissures or shear planes then permits ice at the centre of the glacier to slide faster than ice near the margins. The ice was considered rigid, with each dislocated block sliding independently on its base. Here, Hopkins' ideas were equally original. It was not a case of the ice sliding on its base and retarded by friction, as this could only result in no movement or accelerating motion. Rather, he thought that the ice near the base of the glacier was unable to resist the sliding force and was in a state of disintegration or liquefaction. The glacier was supported on this disintegrating base by the hydrostatic pressure of melt water, and so was sheared easily. His laboratory experiments supported this contention. Field studies had clearly shown that glaciers slid over their beds - this was no longer in doubt - but there was no evidence of such shear planes, nor of staccato movement of blocks of ice across the glacier, a point Forbes (1844) was keen to note as he rejected any hypothesis which denied the fact of viscous flow.

The origin and presence of crevasses needed explanation. Scheuchzer (1723) thought that they formed in summer when air bubbles in the ice expand, Gruner (1760) thought that air was trapped under the ice, and Hugi (1830) considered that thermal stresses would generate them during cold spells. Agassiz (1840, p. 84$)$, amongst others, correctly associated transverse crevassing with a steepening gradient

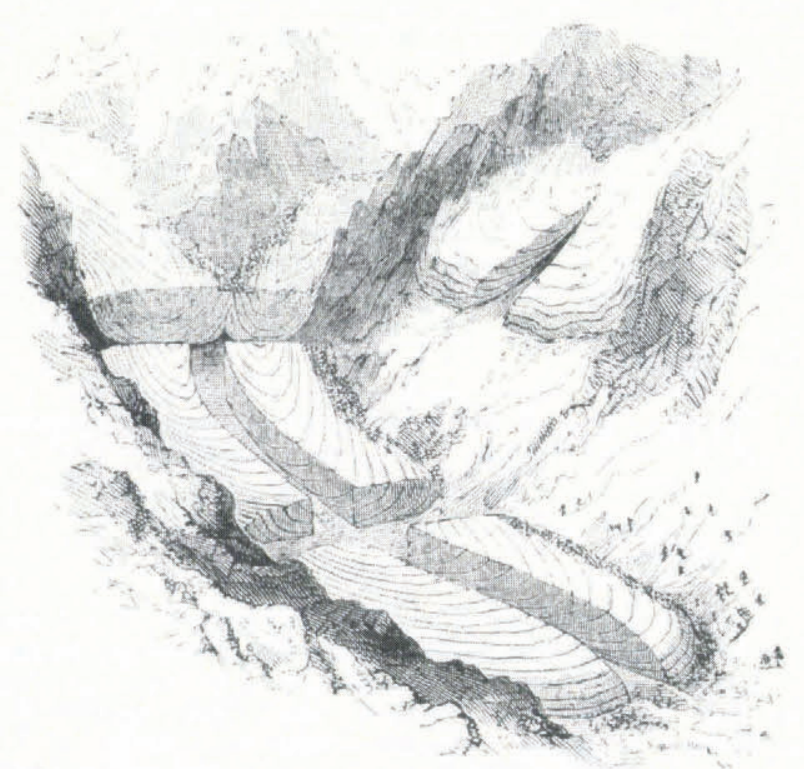

Fig. 2. The three-dimensional form of foliation (the veined structure) in a valley glacier. Forbes argued that the existence of foliation demonstrated the viscous nature of ice. (Reproduced from Forbes (1843b) with the knowledge of $A$. and $C$. Black.) 
where the ice was bent like a beam. The marginal crevasses, close to the valley walls, which form a segment of an arc pointing obliquely up-hill, suggested to early philosophers that the ice at the margins flowed faster than at the centre. However, William Hopkins (1843b) correctly interpreted their formation as arising from the large differential movement near the sides and the active shearing of the ice, consequences of the rapid flow at the centre of the glacier. He resolved the forces into tensile and compressive stresses at right-angles to each other with shear stresses at $45^{\circ}$ to both. The marginal crevasses then opened under tensile stresses acting perpendicular to their length. Hopkins contended that fissuring and shearing as suggested by Forbes (1843a, 1846) could not account for the veined structure (foliation) which ran perpendicular to the marginal crevasses, thereby rejecting the intimate link between flow and glacier structure which was the cornerstone of Forbes' hypothesis. Glacier ice could not simultaneously be in tension in two orthogonal directions to produce both the crevasses and the fracture along the planes of foliation. Foliation is a secondary structure created by deformation of ice at the base of an ice fall and passively transported down-stream. Hopkins was correct in his contention that the bands were not formed in situ as a consequence of intense shearing at that point (Allen and others, 1960), while Forbes correctly deduced their relationship to ice flow.

While little was known about glaciers, little was also known about ice itself. Laboratory experiments were to offer some clues:

(1) Christie (Forbes, 1846) filled an iron shell with water during a severe winter spell. As the water froze, a plug of ice was gradually extruded from the fuse hole. There was no evidence of thawing nor of brittleness.

(2) Professor William Thomson (1850), later Lord Kelvin, suggested that ice should melt under pressure. This he subsequently demonstrated. The theoretical basis was deduced by his brother James. Ice, being less dense than water occupies a larger volume, so when a mixture of the two is compressed some of the ice should melt, thus occupying a smaller volume. However, latent heat is required; this can only be taken from the system as a whole by a general drop in temperature until a new equilibrium with pressure is established (J. Thomson, 1850).

(3) Again, in 1850, Michael Faraday noticed that when two pieces of thawing ice were placed together they froze at the point of contact: a phenomenon called regelation. One puzzle was where could the cold be found to freeze the film of water between the two touching surfaces? (see Faraday, 1861)

Such observations suggested to Tyndall and Huxley (1857) that ice could be moulded under pressure. They demonstrated that blocks of ice when squeezed rapidly would shatter, but with continued pressing these fragments would re-unite into a continuous mass of transparent ice conforming to the shape of the mould. If the ice was too cold, a white powder of fine ice was produced instead. They deduced:

"Though crushed by great pressure, new attachments would be formed by the cementing, through regelation, of the severed surfaces; and that a resemblance to an effect due to viscosity might be produced."

To Tyndall and Huxley (1857), the motion of a glacier was the result of successively occurring fractures, changes of position, and freezing of these pieces in new positions. The ice between the fractures was rigid, brittle, and unyielding, sustaining stresses within the limits of its strength. Audible cracking of ice on a glacier had been remarked on on many occasions (leger bruit de crépitation; Desor). Indeed, Forbes in his poetic final passage of his Travels likened the life of a glacier to that of Man: "it yields groaning to its fate". The fate of a glacier, then, was by rude fracture and regelation, not by viscous yielding.
"The crackling voice of the glacier - a groaning protest against the viscous hypothesis, must be regarded as its grumbling assent to the theory of regelation" (Anonymous, 1857). Not everyone was convinced (Thomson, 1862). John Ruskin (1907, Deucalion), in biting satire, interpreted this theory to mean that "a glacier advances by breaking itself spontaneously into small peices; and then spontaneously sticking the pieces together again".

As befitted his theory, John Tyndall (1873) emphasized the brittleness of ice. A body that was viscous must be capable of being drawn out in tension, yet a glacier in tension was always excessively crevassed and these formed suddenly - like a brittle fracture - but opened slowly. Forbes, on the other hand, viewed crevasses as superficial, penetrating only to a small fraction of the depth of the glacier, being accidents of motion and not the cause. The glacier as a whole was merely scarred and capable of flowing plastically below this superficial layer.

Forbes, Thomson, and Tyndall all believed that water plays an essential role in glacier flow, either directly or by regelation. But there was no general agreement. James Thomson (1857) advanced pressure melting as the common cause. Thus, when ice at $0^{\circ} \mathrm{C}$ is subjected to compressive stresses, melting occurs where the stresses are greatest, heat being supplied through a sensible lowering of the melting point by pressure. The cold evolved in the highly stressed parts of the ice is available to refreeze water once this has escaped to less stressed positions. The yielding of one part of the ice by pressure melting throws the pressure on to another which in turn melts and yields. The cycle repeats itself endlessly, allowing the ice to change its form in the way manifest in glaciers. Thomson (1860) described his theory as that of pressure melting and regelation, whereas he called Tyndall's fracture and congelation - as regelation implies previous melting which was not envisaged by Tyndall. Thomson proposed that while fracture was not the cause of glacier flow, as Tyndall and Huxley advocated, it might be a consequence of the ice yielding in some parts (by pressure melting and regelation) thereby overstraining other parts which fail.

Tyndall and Huxley (1857) recognized that the motion of a glacier was no doubt aided by pressure melting, but this was not deemed sufficient by itself. In a glacier, the heat required for pressure melting must flow continuously through the ice; however, the poor conductivity of ice and the near-zero temperature gradient in a temperate glacier severely limit the heat flux. If the ice were cold $\left(<0^{\circ} \mathrm{C}\right)$, enormous pressures would be needed to melt it before the glacier could flow.

Forbes is perhaps best known for discovering and describing ogives or "Forbes bands" on Mer de Glace at Chamonix. These alternating pairs of wide bands of clear and dirty surface ice fascinated Forbes and later glaciologists. Figure 3, from Tyndall (1872, p. 131), shows their characteristic chevron shape. Forbes (1843b, p. 156), noting that the coloured bands were formed when dirt was trapped in hollows created by differential melting of the veined structure in zones where the ice tended to be more porous, emphasized that the ogive bands were another indication of the close relation between flow and structure in the ice. To Tyndall $(1872$, p. 131), on the other hand, the ogives were purely surficial. He attributed the coloured bands to dirt collected in the hollows of topographic waves formed from traverse ridges of ice (serac blocks) descending the ice fall Seracs de Geant. Animated discussion of ogives has continued for 140 years (see Waddington, 1986).

There was bitter wrangling over precedence of the ideas and observations related to glacier flow. James Forbes' nomination in 1859 for the Copley Medal of the Royal Society was challenged by some who accused him of plagiarism (Huxley, 1873). Three issues were involved: the extent to which Forbes appropriated without acknowledgement other people's ideas of glacier flow, the credit being due to Bordier and Rendu, his conduct towards Agassiz, and whether this viscous flow theory was a theory at all.

On the first point, it is clear that Forbes showed considerable deference to Rendu, readily emphasizing his original contribution (Shairp and others, 1873, p. 521-43). Forbes had only cursorily examined the bishop's work before he began his surveys on the Mer de Glace. His first 
announcements of the viscous flow theory anticedes Rendu's gift of a copy of Theorie de glaciers de la Savoie in the autumn of 1842. Their relations were always cordial: in August 1844, Forbes was invited by the bishop to Annecy. He went in July 1846. Both Forbes and Rendu were unaware of Bordier's (1773) work. That book is a bit of an enigma. Freshfield (1920, p. 193) has queried the authorship of the crucial parts on glacier flow, embedded as it is within a lively but slight narrative. However, ideas of ten have strange parents.

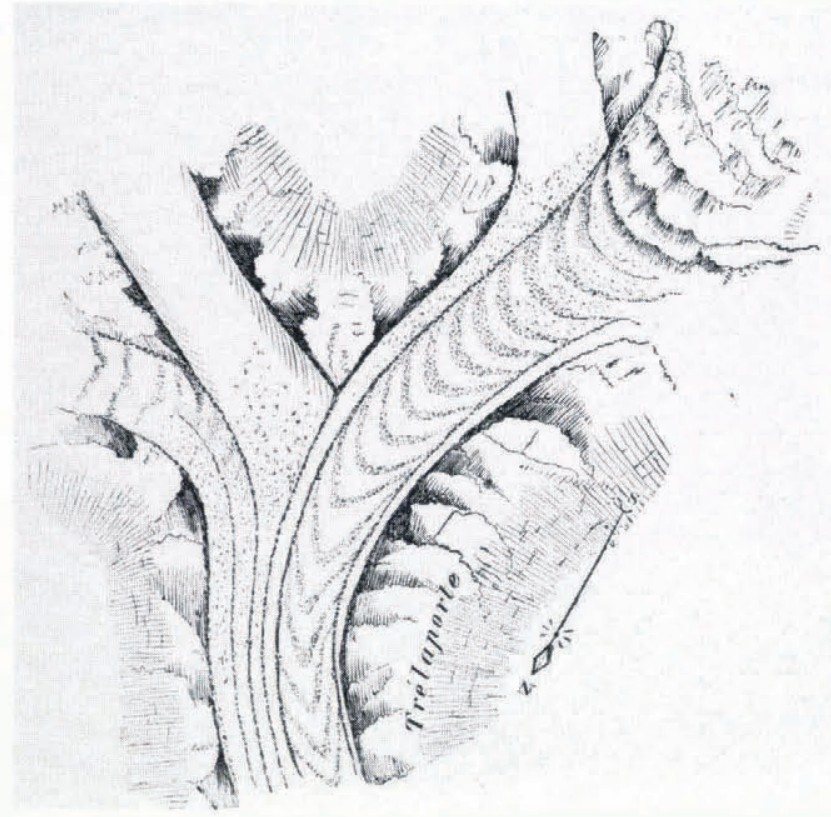

Fig. 3. Ogives or Forbes bands on Mer de Glace at Chamonix. The coloured bands are caused by dirt lying in hollows resulting from differential melting on the foliated structure. (Reproduced from Tyndall (1873) with the knowledge of Appleton and Lange.)

The issue between Agassiz and Forbes is more delicate (Shairp and others, 1873, p. 258-73, 544-59; Tyndall, 1873; and for a recent re-evaluation, Campbell and Hutchinson, 1978). By the time of Forbes' visit to the Aar in 1841, Louis Agassiz had spent 4 years in the study of glaciers and their discussion was free and open. Forbes was surprised at the lack of progress. Agassiz and his colleagues had failed to see significance in the veined structure of the ice nor had they measured the velocity of the glacier; attempts had been made without success but further work was planned. Agassiz was prompted by Forbes to undertake such an experiment that autumn, driving six stakes across the Aar, only to find himself pre-empted by Forbes' meticulous work on the Mer de Glace in 1842. Agassiz felt wronged; Forbes had come to gratify his curiosity, had learnt their plans and departed with no intimation of his following up the subject. What magnificent irony! Agassiz (1837) had scooped a far greater pool from Charpentier and Venetz with his Discours sur l'ancienne extension de glaciers which incorporated their painstaking researches on the extent of past glaciations and their influence on the landscape, with his unwarranted speculations; and again with his publication of Études sur les glaciers (Agassiz, 1840) ahead of Charpentier's (1841) more thoughtful work. Carozzi's excellent commentry on these events is well worth reading (see Agassiz, 1840; Carozzi, 1966). John Ruskin (1907, Fors Clavigera), while not altogether condoning Forbes, offered a sparkling lament for Agassiz's misfortune and humiliation. Even Forbes' detractors (Anonymous, 1857) admitted "in science the race not infrequently is to the swift"; not quite what the preacher had in mind (Ecclesiastes, 9, v. 11). The proprietary right of Agassiz to measurement of ice velocity is disputable. Escher von der Linth (Forbes, 1942b) had already tried unsuccessfully on Aletschgletscher, as had Agassiz on the Aar in the period between the autumn of 1840 and spring of 1841. Lack of results was due partly to the unexpectedly high rates of ablation, toppling survey stakes, and partly to inaccuracies in determining small differences over large distances. Forbes realized that relative movement could be detected more easily and accurately with a theodolite. Both Agassiz (1842b) and Forbes (1842b) published their results in 1842; their observations harmonized in most respects. Agassiz had sought confirmation of what he thought to be true, the dilation theory, and made no comment when the results were contrary to those expected. Forbes considered existing speculations on glacier flow to be bad physics and was anxious to prove something radically new - his viscous flow theory. Priority for discovery of the veined structure in glaciers was also in contention. Agassiz claimed this for himself, only to be embarrassed to learn that Professor Guyot had described it in a paper which he had heard read in 1838. Sir David Brewster (1814) was probably the first to note it. Forbes saw his singular achievement in the causal link which he sought to establish between his glacier-flow measurements and observations of glacier structure. These taken together justified his viscous theory.

The nature of Forbes' theory was the source of the most bitter and acrimonious controversy. Forbes himself was all too aware of the brittle nature of ice and so his espousal of Rendu's idea was a venture of faith which defied contemporary opinion. It is not surprising that he made various contradictory attempts to describe the viscosity of ice. Efforts at clarification caused greater confusion, justifying the suspicion "that the hypothesis of viscosity did not always fully satisfy the mind of its inventor" (Anonymous, 1857). Tyndall's "beautiful" (Forbes' word) experiment was seen at the time as a triumphant demonstration of the plasticity of ice by fracture and congelation, suggesting how a glacier might flow like a viscous fluid; whereas Forbes' earlier ideas, however prescient, had been more speculative, as in his 1846 paper where "bruising, sliding and reattachment" suggested something similar to Tyndall's fracture and congelation. For all his glacier surveys, Forbes had failed to show how his model worked: to demonstrate the viscosity of ice. It is strange that he neglected laboratory studies. Such experiments as had been performed - on pressure melting, regelation, and extrusion - obscured the main question concerning flow within a glacier, primarily because they are not essential for glacier flow. One should note, in parentheses, that the influence of hydrostatic stress superimposed on the deviatoric stress, as in Christie's and in Tyndall and Huxley's laboratory experiments, and in the flow of a glacier, was not remarked on - nor is it clear that the difference was understood.

Campbell and Hutchinson (1978) had the following to say regarding Forbes' visit to the Aar:

"Although Agassiz' and Forbes' relations on the glacier expedition seem to have been cordial, Forbes' later publications show that he had reservations about Agassiz' theoretical abilities, however impressive his practical achievements."

The same could be said of Forbes, who at various times espoused a number of contradictory explanations for the deformation of ice. His sole criterion for acceptance appears to have been that it must be compatible with the observed viscous flow of a glacier.

Forbes was confident of his analysis of the flow pattern of a glacier as a body. His ideas failed to convince when he ventured to the crystalline or molecular level. As late as 1855 he argued (Forbes, 1855):

"The viscosity, though it cannot be "traced" in the parts, if very minute, nevertheless exists there, as unequivocally proved by experiments on the large scale ...".

This conclusion appears to strain the use of the scientific method.

Articles of a scientific nature were widely read by educated people and this sad controversy was waged publicly, at times with evident relish, over a period of 30 years, culminating in a series of vituperative letters to the journal Nature in 1873. Rowlinson (1971) provided an 
excellent review of this controversy. On a more positive note, these scientific papers contained much speculative thinking which contrasts strongly with the measured caution and discursive argument of scientific papers today.

Experiments by Reusch (1864) and in 1866 by Biancioni $(1871,1876)$ were to show that small samples of ice would bend under load - observations that must admit a degree of plasticity. But it was only in the 1880 s that it was generally admitted that ice could be slowly bent or drawn in tension without fracture. These observations mark the threshold of present theories of glacier flow and creep of ice.

\section{REFERENCES}

Agassiz, J.L.R. 1837. Discours sur l'ancienne extension de glaciers. Neuchâtel, Jent et Gassmann.

Agassiz, J.L.R. 1840. Études sur les glaciers. Neuchâtel, Jent et Gassmann.

Agassiz, J.L.R. 1842a. Observations on the glacier of the Aar. Edinburgh New Philos. J., 38, 339-402.

Agassiz, J.L.R. 1842b. Observations sur le glacier de l'Aar. C.R. Acad. Sci. Paris, 15, 284-288.

Agassiz, J.L.R. 1842c. The glacial theory and its recent progress. Edinburgh New Philos. J., 33, 217-283.

Agassiz, J.L.R. 1967. Studies on glaciers, preceded by the Discourse of Neuchâtel translated and edited together with an introduction by A.V. Carozzi. New York and London, Hafner Publishing Co.

Allen, C.R., W.B. Kamb, M.F. Meyer, and R.P. Sharp. 1960. Structure of the lower Blue Glacier, Washington. J. Geol., 68, 601-625.

Altmann, J.G. 1751. Versuch einer historischen und physischen Beschreibung der helvetischen Eisgebirge. Zürich.

Anonymous. 1857. Glaciers and glacier theories. Westminster Rev., 67, 418-444.

Beer, G.R. de. 1953. Bernard Friedrich Kuhn's investigations on glaciers. Ann. Sci., 9, 323-341.

Biancioni, G.G. 1871. Esperienze intorno alla flessibilità del ghiaccio. Mem. Acad. Sci. Inst. Bologna, 1, Ser. 3a, 155-165.

Biancioni, G.G. 1876. Nouvelles expériences sur la flexibilitè de la glace. C. R. Acad. Sci. Paris, 82, 1193-1194.

Bordier, A.C. 1773. Voyage pittoresque aux glacières de Savoie. Geneva.

Bordier, A.C. 1879. Bordier's "Voyages aux glacières". Alpine J., $9(65), 327-333$.

Brewster, Sir D. 1814. Glaciers. Edinburgh encyclopedia, Vol. 10, 283.

Campbell, I. and D. Hutchinson. 1978. A question of priorities: Forbes, Agassiz, and their disputes on glacial observations. Isis, 69, 388-399.

Carozzi, A.V. 1966. Agassiz's amazing geological speculation: the Ice-Age. Stud. Romanticism, 5, 57-83.

Charpentier, H.T. von. 1819. Ueber die Gletscher. Ann. Phys. Phys. Chem., 63, 388-411.

Charpentier, J.G.F. de. 1841. Essai sur les glaciers et sur le terrain erratique du bassin Rhône. Lausanne, Ducloux.

Charpentier, J.G.F. de. 1842. English summary of Essai sur les glaciers et sur le terrain erratique du bassin Rhône. Edinburgh New Philos. J., 33, 104-124.

Clarke, G.K.C. 1987. A short history of scientific investigations on glaciers. J. Glaciol., Special Issue, 4-24.

Faraday, M. 1861. Note on regelation. Philos. Mag., 21, 146-153.

Forbes, J.D. 1842a. Professor Forbes' account of his recent observations on glaciers. Edinburgh New Philos. J., 33, 338-352.

Forbes, J.D. 1842b. The glacier theory. Edinburgh Rev., 75(151), 49-105
Forbes, J.D. 1843a. Recent observations on glaciers. Edinburgh New Philos. J., 34, 1-10.

Forbes, J.D. 1843b. Travels through the Alps of Savoy. Edinburgh, Black.

Forbes, J.D. 1844. Sixth letter on glaciers. Edinburgh New Philos. J., 37, 231-244.

Forbes, J.D. 1846. Illustrations of the viscous theory of glacier motion. Part III. Philos. Trans. R. Soc. London, 136(1), 177-220.

Forbes, J.D. 1855. Remarks on the Rev. H. Moseley's theory of the descent of glaciers. Proc. R. Soc. Edinburgh, 7, 412-417.

Forbes, J.D. 1900. Travels through the Alps of Savoy. New revised edition annotated by W.A.B. Coolidge. Edinburgh, Black.

Freshfield, D.W. 1920. Life of Horace Benedict de Saussure. London, Arnold.

Gruner, G.S. 1760. Die Eisgebirge des Schweizerlandes. Bern, Wagner.

Hopkins, W. 1843a. On the motion of glaciers. Trans. Cambridge Philos. Soc., 8, 50-74.

Hopkins, W. 1843b. On the motion of glaciers. Trans. Cambridge Philos. Soc., 8, 159-169.

Hugi, F.J. 1830. Naturhistorische Alpenreise. Solothurn, Amiet-Lutiger.

Huxley, T.H. 1873. Forbes and Tyndall. Nature, 7, 64.

Moseley, H. 1855. On the descent of glaciers. Proc. R. Soc. Edinburgh, 7, 333-342.

Pálsson, Sveinn. 1945. Jöklaritiđ; frumdrög til lýsingar á stađháttum, sögu og eđlisfari islenzkra jökla. In Pálsson, S. Ferđabók Sveins Pálssonar; dagbakur og ritgerđir 1791-1797. Reykjavík, Snælandsútgáfan, 423-552.

Rendu, L. 1840. Théorie des glaciers de la Savoie. Chambéry.

Reusch, F.E. 1846a. Beiträge zur Lehre vom Eis. Ann. Phys. Chem., 121, 573-575.

Reusch, F.E. 1846b. On some properties of ice. Philos. Mag., 27, 192-194.

Rowlinson, J.S. 1971. The theory of glaciers. Notes Rec. R. Soc. London, 26(2), 189-204.

Ruskin, J. 1907. The works of John Ruskin. Edited by E.T. Cook and A. Webberburn. London, Allen.

Saussure, H.B. de. 1803. Voyages dans les Alpes. Neuchâtel, Fauche.

Scheuchzer, J.J. 1723. Helveticus, sive itinera per helvetiae alpinas regiones facta, annis 1702-11. Leyden, Lugduni Batavorum.

Shairp, J.C., P.G. Tait, and A. Adams-Reilly. 1873. Life and letters of James David Forbes. London, Macmillan.

Thompson, J. 1850. Theoretical considerations on the effect of pressure in lowering the freezing point of water. Cambridge Dublin Math. J., 5, 248-255.

Thompson, J. 1857. On the plasticity of ice, as manifested in glaciers. Philos. Mag., Ser. 4, 14(96), 548-550.

Thompson, J. 1860. On recent theories and experiments regarding ice at or near its melting point. Philos. Mag., 19, 391-397.

Thompson, J. 1862. Note on Professor Faraday's recent experiments on regelation. Philos. Mag., 23, 407-411.

Thompson, W. 1850. The effect of pressure in lowering the freezing-point of water experimentally demonstrated. Philos. Mag., 37, 123-127.

Thorarinsson, S. 1960. Glaciological knowledge in Iceland before 1800. Jökull, 10, 1-14.

Tyndall, J, 1872. The forms of water in clouds and rivers, ice and glaciers. New York, D. Appleton and Co.

Tyndall, J. 1873. Principal Forbes and his biographers. Contemp. Rev., 22, 483-508.

Tyndall, J. and T.H. Huxley. 1857. On the structure and motion of glaciers. Philos. Trans. R. Soc. London, 147(2), $327-346$.

Waddington, E.D. 1986. Wave ogives. J. Glaciol., 32(112), $325-334$ 